\title{
Reducing greenhouse gases using the pay-as-you-throw (PAYT) system
}

\author{
J. H. Kim \\ Seo-Kyeong University, South Korea
}

\begin{abstract}
According to many meteorologists, the annual temperature increase brought about by greenhouse gases (GHG) can heighten the frequency and intensity of extreme precipitation events. These changes will likely be accompanied by a continual rise in sea levels, and may exacerbate already existing natural hazards. Lots of GHG are emitted from waste transportation by trucks, waste combustion in incinerators, and waste decomposition in landfills. Meanwhile, waste collection fee systems in many countries rely heavily on public expenses, resulting in a huge generation of waste. The author argues that a flat waste collection fee system through taxation represents a kind of subsidy that will allow consumers to generate more waste and more GHG emissions. In relative terms, the data from experience regarding the pay-as-you-throw (PAYT) system in the United States can be used to understand the ambiguous relationships between GHG emissions, climate change, and waste generation. Based on data analysis of the PAYT system in US, this paper attempts to develop a sustainable garbage collection and recycling method from the point of view of GHG emissions reduction.
\end{abstract}

Keywords: greenhouse gases, garbage collection fees, recycling methods, waste management, pay-as-you-throw, volume-based-garbage-collection-fee.

\section{Introduction}

For many wastes, landfill is the largest route for disposal throughout the world. The major advantage associated with the landfilling of wastes is the low cost compared with other treatment options - incinerating, composting, and recycling. It is also recognized that many other waste treatment and disposal options require a final disposal route for the residues to be landfilled. However, it 
should be remembered that landfilling is not the final disposal method anymore, since most landfill sites are now sources of pollution with uncontrolled leakages and gases.

\section{Landfill gas and methane $\left(\mathrm{CH}_{4}\right)$}

Landfill gas, in particular, can be hazardous since the largest component, methane $\left(\mathrm{CH}_{4}\right)$, can reach explosive concentrations. Landfill gas methane is also a greenhouse gas that has 20-30 times the effect of carbon dioxide $\left(\mathrm{CO}_{2}\right)$ in instigating the problems of global warming. Waste treatment activities are sources of greenhouse gas emissions and landfills accounted for approximately $24 \%$ of total US anthropogenic methane emissions in 2005. Landfill methane is the largest contribution of any methane source in the United States, and American landfills emit an estimated 7\% of the world's anthropogenic methane [1]. With global warming, a temperature increase of merely a few degrees would cause the landfill methane to volatilize and "burp" into the atmosphere. This would further raise temperatures, which would release more methane, heating the land and seas even more. Similarly, a massive release of $\mathrm{CH}_{4}$ from methane clathrate in the ocean could cause rapid warming, according to the clathrate gun or methane burp hypothesis [2]. One researcher has stated "We can reduce our $\mathrm{CO}_{2}$ emissions from fossil fuels but we could not reduce methane emissions once they started, huge natural forces would take over and change our world" [3]. Utilizing this basis of argument, the present study reviews the changes between waste landfill and climate change in a pay-as-you-throw (PAYT) system. The author is especially interested in PAYT's effect on reducing green house gases (GHG) emissions.

\section{PAYT in the US}

\subsection{What is PAYT?}

According to the US Environmental Protection Agency (EPA), PAYT is the name of unit pricing or variable-rate pricing in a garbage collection fee system. It is also a solid waste management system in which residents are charged for the collection of municipal solid waste based on the amount they throw away. This creates a direct economic incentive to recycle more and to generate less waste. Traditionally, residents paid for waste collection through property taxes or a fixed fee, regardless of how much trash they generated. PAYT breaks this oldfashioned tradition by treating trash services just like other utility service, such as electricity or gas. Households or consumers pay a variable rate depending on how much they use the service.

\subsection{Less waste and more recycling}

Most communities with PAYT charge residents a fee for each bag or bucket of waste they generate. Such systems are simple and fair: the less individuals throw 
away, the less they pay. Communities with PAYT programs in place have reported significant increases in recycling and reductions in waste, due primarily to the waste reduction incentive created by PAYT. Less waste and more recycling mean that fewer natural resources need to be extracted. In addition, GHG emissions associated with the manufacture, distribution, use, and subsequent disposal of products are reduced as a result of the increased recycling and waste reduction. In this way, PAYT helps slow the build-up of GHG in the Earth's atmosphere, which leads to global climate change.

\subsection{Waste reduction and landfill GHG}

\subsubsection{Waste generation}

In the $1960 \mathrm{~s}$, the US's per capita generation of waste was $1.2 \mathrm{~kg} /$ person per day, and the total national waste generation was 88.1 million tons. Along with increased concerns over indiscriminate waste disposal, Congress passed a landmark legislation covering waste disposal called the Resource, Conservation and Recovery Act (RCRA) in 1976. The RCRA initiated the defining, separation, and separate disposal requirement of hazardous and non-hazardous wastes. The act was an innovative amendment to the Solid Waste Disposal Act of 1965, which was the first federal statutory measure to improve solid waste disposal activities. The RCRA has been amended several times since 1976 in the Hazardous and Solid Waste Amendments of 1984; the Federal Facilities Compliance Act of 1992; and the Land Disposal Program Flexibility Act of 1996 [4]. However, US residents, businesses, and institutions still produced more than 251 million tons of Municipal Solid Wastes (MSW) in 2006. As the population of the US has risen to 303 million, the amount of waste is now approximately $2.27 \mathrm{~kg} /$ person per day. The median family income level of the US, \$58,526, is better than that of other average OECD countries. Nevertheless, few can deny that the US MSW is relatively over-generated in comparison to that of other countries.

\subsubsection{Effects of PAYT on waste reduction}

According to Skumatz Economic Research Associates (SERA)'s research, PAYT's effect on waste generation was a decreasing residential MSW. There was a $14-17 \%$ reduction in weight of waste, with $8-11 \%$ diverted directly to recycling, and another $6 \%$ decreased by source-reduction efforts. The reports also found that an additional 5-6\% may be indirectly attributed to recycling [5]. The research also estimated the tons diverted annually as a result of recycling, composting, and source reduction - and the total tonnage diverted from landfills. The figures, presented in Table 1, show that the current PAYT programs divert approximately $17.5 \%$ of MSW from landfills annually.

According to the related experience of Metropolitan Seoul region, Korean PAYT's effect (i.e. Korean VGCF; volume-based-garbage-collection-fee) on waste generation was a decreasing residential MSW in 10 years. There was a $24.1 \%$ reduction in weight of waste, with $103.4 \%$ increase of recycling materials, and another $57.1 \%$ decreased by source-reduction efforts [6]. 
Table 1: $\quad$ US residential MSW tonnage covered by PAYT programs.

\begin{tabular}{|l|c|}
\hline Computation element & Amount (ton) \\
\hline Residential tons affected & $47,407,500(100 \%)$ \\
$\quad$ - New tons to recycling: 6\% & \\
$\quad$ - New tons to composting: 5.5\% & \\
$\quad$ - New tons to source reduction: 6\% & \\
Total new tons diverted from landfill & $8,296,313(17.5 \% \downarrow)$ \\
\hline PAYT effect on waste diversion ratio from landfill $17.5 \%$ \\
\hline
\end{tabular}

Source: Skumatz and Freeman [5].

Table 2: $\quad$ FY 2004's Policy performance of Seoul PAYT system in Korea*.

\begin{tabular}{|c|c|}
\hline Before Seoul PAYT (1994) & After Seoul PAYT(2004) \\
\hline 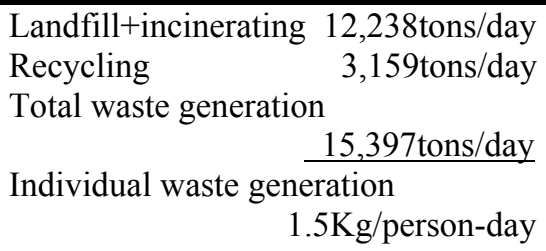 & $\begin{array}{l}\text { Landfill+incinerating } 5,247 \text { tons/day } \\
\text { Recycling } 6,426 \text { tons/day } \\
\text { Total waste generation } \\
\frac{11,673 \text { tons/day }}{\text { Individual waste generation }} \\
1.1 \mathrm{Kg} / \text { person-day }\end{array}$ \\
\hline Waste reduction ratio by PAYT & $24.1 \%$ \\
\hline
\end{tabular}

* PAYT or VGCF system started from 1995 in Korea [6].

\section{Effects of PAYT on GHG emissions}

\subsection{Effects of PAYT on landfill gases}

As suggested in Table 1, PAYT's impact on the MSW landfill reduction ratio can be as high as $17.5 \%$. Moreover, beyond its direct effect, PAYT can indirectly influence raw material acquisition, as well as manufacturing. For example, all products use inputs of raw materials, such as metal ore, petroleum, trees, etc. Extracting and transporting these materials entail the combustion of fossil fuels for energy, resulting in $\mathrm{CO}_{2}$ emissions [7]. PAYT can be influential not only for consumers but also for manufacturers.

\subsection{Effects of PAYT on GHG emissions}

Landfill, especially, results in the release of $\mathrm{CH}_{4}$ from the anaerobic decomposition of organic methane materials. $\mathrm{CH}_{4}$ is $20-30$ times more potent a GHG than $\mathrm{CO}_{2}$. However, PAYT can be a catalyst for diverting a lot of materials to recycling instead of landfills. The material stream is easily changing from a waste-oriented system to a recovery-oriented system. This current seems to lead to less landfill and fewer GHG emissions. If the American MSW can be reduced by $17.5 \%$ by executing PAYT in every city and town in the United States, the 
reduced MSW amount will be approximately 43.9 million tons/year. This PAYT effect can prevent the release of over 25 million metric tons of carbon into the air-roughly the amount emitted annually by 20 million cars, or 650 trillion BTUs $(1 \mathrm{BTU}=252 \mathrm{cal})$, saving energy equivalent to 5 billion gallons of gasoline.

\section{Effects of PAYT on GHG emissions in Massachusetts}

\subsection{Municipal solid waste: US vs. State of Massachusetts}

The total population of the US is 303 million. The median family income is $\$ 58,526$, and the amount of MSW was approximately 251 million tons in 2006 . This means that the MSW disposal amount of every average American is 2.27 $\mathrm{kg}$ /day. In comparison with the MSW data for the US, the data for Massachusetts are something different [8]. The total population of Massachusetts is 6.4 million residents. The median family income is $\$ 74,464$, and the amount of MSW was 5.8 million tons in 2006. This means the MSW disposal amount of every average Massachusetts resident is $2.49 \mathrm{~kg} /$ day.

Table 3: $\quad$ Municipal solid waste data on US vs. Massachusetts.

\begin{tabular}{|c|c|}
\hline \multirow{3}{*}{$\begin{array}{l}\text { US } \\
(2006)\end{array}$} & $303,000,000$ (303 million residents) \\
\hline & Median Family Income $\quad \$ 58,526$ (average family size $=3.20$ ) \\
\hline & $\begin{array}{r}251,000,000(251 \text { million tons of MSW }) \\
2.27 \mathrm{~kg} / \text { person-day }\end{array}$ \\
\hline \multirow{3}{*}{$\begin{array}{l}\text { MASS } \\
(2006)\end{array}$} & $6,400,000$ (6.4 million residents) \\
\hline & Median Family Income $\$ 74,463$ (average family size=3.17) \\
\hline & $\begin{array}{r}5,829,753(5.8 \text { million tons of MSW }) \\
2.49 \mathrm{~kg} / \text { person-day } \\
\end{array}$ \\
\hline \multicolumn{2}{|c|}{$\begin{array}{l}\text { *) } \mathrm{MSW}=\text { domestic transfer 4,960,715 + exporting } 1,600,000 \text { ton } / \mathrm{yr} \\
\mathrm{MSW} \text { Disposal }=\text { incineration 3,221,869 + landfills } 2,607,884 \text { ton/yr } \\
(+ \text { ash \& sludge residuals etc. } 869,038 \text { ton/yr })\end{array}$} \\
\hline
\end{tabular}

Source: MA documents, 2006; US Census, 2006; US EPA, 2006 [10-12].

Based on the level of income, Massachusetts' MSW disposal can be estimated at $2.49 \mathrm{~kg} /$ person-day. Although the amount is more than the US average, it is relatively less than expected. Both the exporting and domestic landfill amounts to $4,207,884$ tons/year, which is very similar to the US landfill ratio of $64 \%$. 


\subsection{Today's Massachusetts PAYT}

In 1995, Massachusetts' Department of Environmental Protection (DEP) made a state-level decision to promote a flexible PAYT program that allows each community to develop a program that fits its individual circumstances. Massachusetts owes its high record of success to informative outreach and educational programs that provide municipal decision-makers with the tools they need to understand how PAYT programs work. The other important example of the state government's support of municipalities is the PAYT Grant Program, which offers grants to qualified municipalities instituting a new PAYT program [12]. As of 2006, 120 of the state's 351 municipalities had implemented a PAYT program $(34.2 \%)$.

\subsection{Estimating PAYT's effects on metro Boston}

Recently, most scientists have come to agree that the changes in the atmospheric GHG abundance alter the energy balance of the climate. However, it is difficult to verify many of climate change hypotheses in relation to carbon dioxide, methane, and other GHG. The scientific community has not reached a consensus on the percentage at which each GHG becomes harmful or has deteriorative effects on climate change. We do not know how much the climate will change, at what rate it will change, or even what the exact effects of this change will be on the climate. In the Climate's Long-term Impacts on Metro Boston (CLIMB) model, total property and contents damages due to relative sea level rise (SLR) over the next 100 years could range from $\$ 20$ billion to $\$ 94$ billion if there are no adaptive responses. Most ocean cities should invest a lot of money to strengthen infrastructure such as city drainage systems so that they can withstand more intense rainstorms. In this context, we have to reconsider all possibilities of climate change disaster prevention by reducing GHG. Among these possibilities, PAYT is an easily and cheaply implemented system that can reduce GHG, including methane.

\subsection{Forecasting PAYT value in metro Boston}

As described by the CLIMB model, most coastal cities will suffer from higher flood risks in the near future. With climate change, higher temperatures and changing precipitation patterns can occur. These changes will likely be accompanied by a continual rise in sea levels, and may exacerbate already existing natural hazards. In this context, can a way be found to reduce GHG emissions at low administrative burdens? One hundred and twenty innovative communities in Massachusetts' are already trying to find the way using their PAYT system. This system is now lessening carbon dioxide, methane, and nitrous oxide from hauler trucks, incinerators, and landfills by way of less waste treatment and more recyclable goods collection. 
Table 4: $\quad$ Forecasting PAYT value in metro Boston.

\begin{tabular}{|lr|}
\hline \multicolumn{2}{|l|}{ Metro Boston's 101 Municipalities (2006) } \\
\hline Non- PAYT 81 Municipalities of Metro Boston (if they do PAYT) \\
- Reducing MSW disposal & 468,251 ton/year \\
- Reducing Methane $\left(\mathrm{CH}_{4}\right)$ & 34,182 ton/year \\
PAYT Effect on Diminishing Climate Change Risk & \\
- Additional Residential Flood Damage* & $\$ 24.2$ million /year \\
\hline PAYT Value & \\
- Tipping Fee Reduction & $\mathbf{\$ 3 7 . 4}$ million/year \\
- GHG Permit Trading Value & $\mathbf{\$ 4 . 2}$ million/year \\
- Additional flood damage prevention Value & $\mathbf{\$ 2 4 . 2}$ million /year
\end{tabular}

Forecasted Total Value (Outcome) of PAYT in Metro Boston

$\$ 65.8$ million /year

(without additional cost)

* CLIMB Model (Hypothesis I).

\section{Conclusion}

PAYT is already a verified method to reduce a lot of GHG by reducing waste in landfills. Because citizens pay their garbage fee according to their throwaways, PAYT can reduce a lot of landfill materials without a lot of additional cost. Moreover, free collection on recyclable materials can give strong incentives for ordinary citizens to participate in the system. If most Americans participate in PAYT across the country, there will be a reduction of MSW of 43.9 million tons annually. US EPA says that the effect of this could be the reduction of approximately 25 million tons of carbon into the air. Fortunately, Massachusetts' many innovative communities are already trying to find the way using their PAYT system. The system is now lessening carbon dioxide, methane, and nitrous oxide from hauler trucks, incinerators and landfills by way of less waste treatment and more recyclable goods collection. In the process of this research, the author found a lot of successful PAYT executive methods in many of Massachusetts' municipalities. For the future, the various kinds of PAYT experimental policies implemented by Massachusetts' state and local governments will be crucial sources for rewriting the American Resource, Conservation and Recovery Act (RCRA). Furthermore, the old fashioned waste collection and disposal system should eventually be changed. The system should move from a flat waste collection fee system by taxation (political trick) to PAYT with free kerbside collection on recyclables (rational citizen participation). As Donald Kennedy said, "We are undertaking a vast experiment with Earth's climate. We're not doing it to test a hypothesis...We're doing it because we can't help it. But since we are doing it, we can at least start behaving like good experimenters" [1]. 


\section{References}

[1] Hill, M. K. Understanding Environmental Pollution, MA: Cambridge University Press, pp.166-167, 2004.

[2] Schmidt, G.A. \& D.T. Shindell. Atmospheric composition, radiative forcing, and climate change as a consequence of a massive methane release from gas hydrates. Paleoceanography 18, pp.1004-1005, 2003.

[3] Archer, D. Methane hydrates and anthropogenic climate change. Dept. of Geophysical Sciences, University of Chicago. 2005.

[4] Williams, P. T. 2005. Waste Treatment and Disposal. UK: Wiley Co.

[5] Skumatz, L. and Freeman, D., Pay As You Throw (PAYT) in the US: 2006 Update and Analyses (PDF), prepared for U.S. EPA and SERA, by Skumatz Economic Research Associates, Superior CO. 2006.

[6] Kim, J.H., Renewing an urban waste management system in an energy crisis: the volume-based garbage collection fee (VGCF) system in Korea and USA. Waste Recycling and Management Research 13(2), pp.59-62, 2008.

[7] Canterbury, J. and Eisenfeld, S., The Rise and Rise of Pay-As-You-Throw. MSW Management, Elements. 2006.

[8] Lambert, J., Personal communication 2007-2008, PAYT director of Massachusetts State Government, USA.

[9] Kirshen, P.H. and M. Ruth, Infrastructure Systems, Services and Climate Change: Integrated Impacts and Response Strategies for the Boston Metropolitan Area, Report to the US EPA. 2004.

[10] U.S. Census. http://factfinder.census.gov/servlet

[11] US EPA, http://www.epa.gov/epaoswer/osw/mission.htm

[12] US Massachusetts State Gov., http://www.mass.gov/dep/recycle/solid 